\title{
PENDAMPINGAN SUAMI TERHADAP KELANCARAN PROSES PERSALINAN DI BPM ARIFIN S SURABAYA
}

\author{
Irmah Nur Lailia*, Fauziyatun Nisa** \\ (UNUSA, FKK, Prodi D III Kebidanan - J1. Smea 57 Surabaya) \\ Email : fauziyatun.nisa@unusa.ac.id
}

\begin{abstract}
The continuity of laboring process can be seen from the length of delivery takes and do not undergo complications during childbirth. In fact, there are many women who have suffered due to an excessive fearness therefore they had labor disfluencies which can be hindering the delivery process of laboring. This study aims to determine the relationship between mentoring husband with the continuity of labor process in BPM Arifin $S$ Surabaya.The design which is used is analytic cross-sectional study design. The population study is all women who is giving birth in the moment of January to May with 142 respondents. The sampling technique using simple random sampling, 61 respondents. The independent variable (mentoring husband) with the dependent variable (continuity laboring process). The collecting data using partograf. Data anlysis using Chi-Square $\alpha=0.05$.The results showed that $85.3 \%$ of respondents who accompanied by husband during laboring process, they will have precious continuity of laboring. The results of chi-square test with $\alpha=$ 0.05 is $\rho=0.000$ obtained significant $\rho<\alpha H_{o}$ have been ignored, it means that there is a relation between accompanied husband and the continuity laboring process.The concusions of this study, there is a relation between accompanying by husband while laboring process and a fluency of laboring process. Unaccompanied by husband while labor process will increase the risk uncontinuity of laboring process. Hence, this is truly necessary for husband having counseling about the importance of accompanying mothers while laboring process.
\end{abstract}

Abstrak : Kelancaran proses persalinan dapat dilihat dari lamanya proses persalinan berlangsung serta tidak mengalami komplikasi saat persalinan. Kenyataannya, masih banyak ibu bersalin yang mengalami ketidaklancaran proses persalinan dikarenakan mengalami ketakutan yang berlebih sehingga menghambat proses persalinan. Penelitian ini bertujuan untuk mengetahui hubungan antara pendampingan suami dengan kelancaran proses persalinan di BPM Arifin S Surabaya.Desain yang digunakan bersifat analitik dengan rancang bangun penelitian cross sectional. Populasi penelitian yaitu semua ibu bersalin pada bulan Januari-Mei sebesar 142 responden. Teknik pengambilan sampel menggunakan simple random sampling, sebesar 61 responden. Variabel independen (pendampingan suami) dengan variabel dependen (kelancaran proses persalinan). Pengumpulan data menggunakan partograf. Analisa data dengan menggunakan uji chi-square dengan $\alpha=0,05$.Hasil penelitian menunjukkan bahwa $85,3 \%$ responden yang didampingi selama proses persalinan mengalami kelancaran. Hasil uji chi-square dengan $\alpha=0,05$ didapat nilai $\rho=0,000$ yang berarti $\rho<\alpha$, $\mathrm{H}_{0}$ ditolak, artinya ada hubungan antara pendampingan suami dengan kelancaran proses persalinan.

Simpulan penelitian ini ada hubungan antara pendampingan suami dengan kelancaran proses persalinan. Persalinan tanpa pendamping akan menambah resiko terjadinya persalinan tidak lancar. Oleh karena itu perlu adanya penyuluhan pada suami mengenai pentingnya pendampingan ibu bersalin.

Kata kunci : pendampingan suami, kelancaran proses persalinan. 


\section{PENDAHULUAN}

Penurunan angka kejadian komplikasi persalinan diperlukan peran serta keluarga (terutama suami), hal ini sejalan dengan kebijakan dan strategi pemerintah dalam rangka menurunkan angka kejadian komplikasi persalinan di Indonesia melalui program MPS (Making Pregnancy Safer). Hasil yang diharapkan dari strategi tersebut adalah meningkatkan peran aktif keluarga selama kehamilan dan persalinan (Depkes, 2004).

Kelancaran proses persalinan dapat dilihat dari lamanya proses persalinan berlangsung serta tidak mengalami hambatan dan komplikasi saat persalinan (Asrinah, 2010). Pada kenyataannya, masih banyak ibu bersalin yang mengalami ketidaklancaran proses persalinan yakni melewati garis waspada pada lembar observasi partograf. Hal ini dikarenakan banyak ibu bersalin yang mengalami ketakutan dan kecemasan yang berlebih sehingga mengganggu kontraksi yang dapat menghambat proses persalinan.

Menurut Thaibatun Nisa dalam penelitiannya berjudul "Hubungan Peran Suami Terhadap Proses Kelancaran Persalinan Normal Pada Ibu Primipara Di Rumah Sakit Umum Daerah Pidie Jaya" didapatkan hasil bahwa ibu bersalin yang mendapatkan dukungan fisik yang baik, sebesar $76 \%$ mengalami kelancaran proses persalinan dan 24\% mengalami proses persalinan tidak lancar. Sedangkan ibu bersalin yang mendapatkan dukungan psikis yangbaik, sebesar $84 \%$ mengalami kelancaran proses persalinan dan $16 \%$ lainnya mengalami proses persalinan tidak lancar. Berdasarkan studi pendahuluan yang telah dilakukan pada tanggal 24 - 28 Maret 2014 di BPM Ny. Arifin S dengan mengambil 6 responden didapatkan 3 orang (50\%) ibu yang bersalin didampingi suami dan proses persalinan berjalan lancar tanpa komplikasi dan tidak melewati garis waspada pada partograf, 3 orang lainnya $(50 \%)$ tidak didampingi suami didapatkan proses persalinan berjalan tidak lancar atau mengalami kesulitan dan perpanjangan kala.

Faktor-faktor yang mempengaruhi kelancaran proses persalinan diantaranya adalah : power (his, tenaga meneran), passage, passenger (janin, plasenta), psikis (salah satunya dipengaruhi oleh pendamping persalinan), posisi, tempat persalinan, dan penolong. Seorang ibu yang memasuki masa persalinan akan muncul perasaan takut, khawatir, ataupun cemas. Ketakutan yang sering dirasakan oleh ibu yang melahirkan, disebabkan oleh ketakutan dengan kondisi janinnya dan ketakutan akan rasa sakit. Rasa takut tersebut akan menimbulkan stress dan memacu keluarnya hormon adrenalin yang akan mengakibatkan penyempitan pembuluh darah dan mengurangi aliran darah yang membawa oksigen ke rahim sehingga terjadi penurunan kontraksi rahim yang dapat menghambat proses persalinan. Kondisi ini akan meningkatkan angka komplikasi persalinan seperti perdarahan dan infeksi yang akan menyebabkan peningkatan angka kematian ibu.

Persalinan sebagian besar dapat berjalan lancar, tetapi bukan berarti tanpa bahaya karena perubahan keadaan dapat terjadi setiap saat yang membahayakan ibu maupun janin. Dengan demikian setiap persalinan selalu memerlukan pengawasan sehingga pertolongan yang tepat dapat diberikan. Kehadiran seorang pendamping persalinan selama proses persalinan akan membawa dampak yang baik, karena dapat memberikan rasa nyaman, aman. Semangat serta dukungan emosional yang dapat membesarkan hati, mengurangi rasa sakit dan mempercepat proses persalinan (Latipun, 2010).

Persalinan yang tidak didampingi akan menimbulkan dampak perasaan takut yang dapat menimbulkan ketegangan sehingga menyebabkan gangguan his, dan akhirnya persalinan berjalan tidak lancar. Pendamping persalinan memegang peranan penting dalam proses kelahiran. Dukungan yang penuh kasih mengurangi 
kebutuhan ibu terhadap obat pereda nyeri dan campur tangan medis dalam persalinannya (Nolan, 2004)

Kebijakan di tempat bersalin mengijinkan suami atau anggota keluarga lainnya menemani ibu waktu bersalin. Bidan harus selalu mengingatkan dari awal pada suami, bahwa pendampingan suami akan berpengaruh pada proses persalinan istrinya. Bidan juga memberikan pengarahan bahwasanya, seorang ibu hamil pasti akan mengalami katakutan tersendiri menjelang proses persalinan, dan jika pada saat persalinan ada pendamping sudah bisa dipastikan ibu akan merasa tenang, aman dan nyaman karena ada suami yang mendampinginya.

\section{METODE}

Jenis penelitian yang akan digunakan adalah analitik dengan tujuan untuk mencari hubungan pendampingan suami dengan kelancaran proses persalinan di BPM Arifin S. Berdasarkan waktunya, desain penelitian yang digunakan adalah Cross Sectional, yaitu dimana variabel independen dan dependen diobservasi sekaligus pada waktu yang sama. Populasi penelitian ini adalah semua ibu yang bersalin pada bulan Januari-Mei 2014 di BPM Arifin $\mathrm{S}$ dengan jumlah persalinan sebesar 142 orang. Sampel pada penelitian ini adalah sebagian ibu yang bersalin pada bulan Januari-Mei 2014 di BPM Arifin S Surabaya. Dalam penelitian ini pemilihan sampel dilakukan secara probability sampling dengan teknik simple random sampling, dimana semua ibu yang bersalin di BPM Arifin S mendapatkan kesempatan yang sama dalam pemilihan responden setelah dilakukan pengundian atau acak.

Dalam analisis data pada penelitian ini menggunakan uji signifikansi yang bertujuan untuk mengetahui keeratan hubungan antara variabel digunakan uji korelasi chi square dengan kemaknaan $\alpha=$ 0,05 , kemudian dianalisis dengan bantuan perhitungan komputer SPSS for windows. Bila didapatkan $\rho<\alpha$ maka H0 ditolak artinya ada hubungan antara pendampingan suami dengan kelancaran proses persalinan.

\section{HASIL DAN PEMBAHASAN}

Karakteristik responden berdasarkan pendampingan suami saat persalinan

Tabel 1. Distribusi frekuensi berdasarkan pendampingan suami di BPM Arifin S bulan Januari-Mei 2014.

\begin{tabular}{|c|c|c|c|}
\hline No & $\begin{array}{c}\text { Pendampinga } \\
\text { n Suami }\end{array}$ & $\begin{array}{c}\text { Jumla } \\
\mathrm{h}\end{array}$ & $\begin{array}{c}\text { Persentas } \\
\text { e }(\%)\end{array}$ \\
\hline 1. & Didampingi & 34 & 55,7 \\
\hline 2. & $\begin{array}{l}\text { Tidak } \\
\text { didampingi }\end{array}$ & 27 & 44,3 \\
\hline & Jumlah & 61 & 100 \\
\hline
\end{tabular}

Sumber : Data Sekunder

Berdasarkan tabel 1. menunjukkan bahwa sebagian besar $(55,7 \%)$ responden didampingi suami saat proses persalinan.

Tabel 2. Distribusi frekuensi berdasarkan kelancaran proses persalinan di BPM Arifin S bulan Januari-Mei 2014

\begin{tabular}{cccc}
\hline No. & $\begin{array}{c}\text { Kelancaran } \\
\text { Proses } \\
\text { Persalinan }\end{array}$ & Jumlah & $\begin{array}{c}\text { Persentase } \\
(\%)\end{array}$ \\
\hline 1. & Lancar & 36 & 59,0 \\
2. & Tidak lancar & 25 & 41,0 \\
\hline & Jumlah & 61 & 100
\end{tabular}

Sumber : Data Sekunder

Berdasarkan tabel 2 menunjukkan bahwa sebagian besar $(59,0 \%)$ responden mengalami persalinan lancar.

Tabulasi silang hubungan antara pendampingan suami dengan kelancaran proses persalinan

Data ini menggambarkan variabel yang diukur dan disajikan dalam bentuk tabulasi silang, data tersebut meliputi hubungan antara pendampingan suami dengan kelancaran proses persalinan dapat dilihat pada tabel 3 berikut ini : 
Tabel 3. Hubungan antara pendampingan suami dengan kelancaran proses persalinan di BPM Arifin S Surabaya.

\begin{tabular}{cccc}
\hline $\begin{array}{c}\text { Pendampingan } \\
\text { Suami }\end{array}$ & \multicolumn{2}{c}{$\begin{array}{c}\text { Kelancaran } \\
\text { Proses } \\
\text { Persalinan }\end{array}$} & Jumlah \\
& Lancar & Tidak \\
& \multicolumn{3}{c}{ Lancar } \\
\cline { 2 - 4 } & $\mathrm{n}(\%)$ & $\mathrm{n}(\%)$ & $\Sigma(\%)$ \\
\hline Didampingi & 29 & 5 & 34 \\
Tidak & $(85,3)$ & $(14,7)$ & $(100)$ \\
didampingi & 7 & 20 & 27 \\
& $(25,9)$ & $(74,1)$ & $(100)$ \\
\hline Jumlah & 36 & 25 & 61 \\
& $(59,0)$ & $(41,0)$ & $(100)$ \\
\hline
\end{tabular}

Berdasarkan tabel 3.telah didapatkan data hasil penelitian dimana dari $34 \mathrm{ibu}$ bersalin yang didampingi suami saat proses persalinan hampir seluruh $(85,3 \%)$ responden mengalami proses persalinan yang lancar. Sedangkan dari $27 \mathrm{ibu}$ bersalin yang tidak didampingi suami saat proses persalinan sebagian besar $(74,1 \%)$ mengalami proses persalinan yang tidak lancar.

Hasil perhitungan menggunakan uji $C h i$ Square didapatkan nilai $\rho=0,000$ dan $\alpha=$ 0,05 . Karena $\rho(0,000)<\alpha(0,05)$, maka hipotesis nihil $\left(\mathrm{H}_{0}\right)$ ditolak yang artinya ada hubungan antara pendampingan suami dengan kelancaran proses persalinan.

\section{PEMBAHASAN}

1. Pendampingan Suami

Hasil penelitian pada tabel 5.4 menunjukkan bahwa sebagian besar $(55,74 \%)$ ibu bersalin saat proses persalinan didampingi oleh suami. Suami adalah anggota keluarga ibu yang paling dekat dan lebih mengerti kebutuhan ibu yang sangat membutuhkan dukungan emosional dan fisik pada saat proses persalinan. Sesuai dengan pendapat Rohma (2010) bahwa dukungan yang terus menerus dari seorang pendamping persalinan kepada ibu selama proses persalinan dan melahirkan dapat mempermudah proses persalinan dan melahirkan itu sendiri, mengurangi kebutuhan tindakan medis.

Pendampingan suami saat persalinan mempunyai peranan penting bagi ibu karena dapat mempengaruhi psikologis ibu. Kondisi psikologis yang nyaman, rileks dan tenang dapat terbentuk melalui dukungan kasih sayang keluarga. Bentuk dukungan bisa berupa support mental, berbagi pengalaman saat menjalani proses persalinan, atau hal-hal positif lain, sehingga berpengaruh pada kekuatan ibu saat melahirkan bayinya. Menurut Bobak (2005) peran pendamping persalinan dipengaruhi oleh beberapa faktor, yaitu : sosial ekonomi, budaya, lingkungan, pengalaman, umur, dan pendidikan.

Pengalaman ibu bersalin dapat mempengaruhi kebutuhan ibu akan pendampingan saat melahirkan. Pada tabel 5.3 didapatkan bahwa dari 61 responden sebagian besar $(62,3 \%)$ adalah ibu multigravida. Karena ibu merasa bahwa pada persalinan yang lalu ketika didampingi suami, ibu merasa lebih nyaman, rileks, dan tenang sehingga ibu ingin didampingi suami kembali saat proses persalinan yang sekarang. Hal ini sesuai dengan teori Richard dan Diane (2009) bahwa keadaan psikologis ibu akan mempengaruhi proses persalinan sehingga dibutuhkan dukungan dari seorang suami minimal berupa sentuhan dan kata-kata pujian yang dapat membuat nyaman, memberi penguatan, dan meningkatkan keharmonisan keluarga.

Pendidikan ibu juga dapat mempengaruhi kebutuhan pendampingan suami saat melahirkan. Tabel 5.2 menunjukkan bahwa sebagian besar $(75,4 \%)$ responden berpendidikan menengah (SMA). Semakin tinggi pendidikan, semakin tinggi pula pengetahuan yang dimiliki seseorang. Ibu yang berpendidikan menengah keatas, memiliki pengetahuan yang cukup sehingga lebih mudah menangkap informasi termasuk pengetahuan tentang pentingnya pendampingan suami saat proses persalinan. Sehingga diharapkan 
kondisi ibu menjadi lebih baik. Sesuai dengan teori Notoatmodjo (2007) menyatakan bahwa semakin tinggi tingkat pendidikan seseorang akan semakin mudah dia menyerap informasi yang diterima.

2. Kelancaran proses persalinan

Hasil penelitian pada tabel 5.5 menunjukkan bahwa sebagian besar $(59,0 \%)$ ibu bersalin mengalami proses persalinan yang lancar. Persalinan yang lancar dapat dilihat pada lembar partograf. Pada kala I, persalinan dikatakan lancar apabila tidak melewati garis waspada pada kolom pembukaan serviks. Sedangkan, pada kala II dilihat dari waktu pembukaan serviks lengkap sampai bayi lahir. Kala III dapat dilihat pada data persalinan, lama kala III tidak boleh lebih dari 30 menit. Dari 61 responden, ada hampir setengah (49,0\%) responden mengalami persalinan yang tidak normal. Pada kala I terdapat 21 responden yang pada partografnya melewati garis waspada, 2 responden yang mengalami ketidaklancaran pada kala II, 1 responden pada kala III dan 2 responden mengalami komplikasi perdarahan.

Kelancaran proses persalinan dipengaruhi oleh beberapa faktor diantaranya : power, passage, passenger, psikis, dan posisi (Lowdermilk, 2013). Salah satu faktor yang mempengaruhi proses persalinan adalah power. Kekuatan berasal dari perubahan fisiologis ibu bersalin itu sendiri dan dari tenaga meneran ibu. Seorang ibu bersalin memerlukan tenaga meneran yang kuat untuk membantu memperlancar proses persalinannya. Kekuatan untuk meneran dipengaruhi oleh faktor usia. Semakin tua usia ibu bersalin, maka kondisi tubuh ibu bersalin semakin melemah.

Hasil penelitian pada tabel 5.1 menunjukkan bahwa hampir seluruhnya (86,9\%) ibu yang bersalin berusia 20-35 tahun yang dikenal dengan usia produktif, sehingga ibu masih cukup kuat untuk meneran saat persalinan dan memiliki resiko terjadi komplikasi yang kecil pada saat persalinan. Ini sesuai dengan teori Wiknjosastro (2005), bahwa pada usia 20-
35 tahun merupakan masa subur atau produktif dimana organ-organ reproduksi sudah sempurna. Dan menurut Lowdermilk (2013), usia lebih dari 35 tahun beresiko terhadap gangguan atau komplikasi yang dapat mempengaruhi kehamilan dan persalinan.

3. Hubungan antara pendampingan suami dengan kelancaran proses persalinan

Hasil tabulasi silang pada tabel 5.6 didapatkan bahwa dari 34 ibu bersalin yang didampingi suami saat proses persalinan hampir seluruh $(85,3 \%)$ mengalami persalinan yang lancar dan sebagian kecil $(14,7 \%)$ mengalami proses persalinan yang tidak lancar. Sedangkan dari 27 ibu bersalin yang tidak didampingi suami pada saat proses persalinan sebagian besar $(74,1 \%)$ mengalami proses persalinan yang tidak lancar dan sebagian kecil $(25,9 \%)$ mengalami proses persalinan yang lancar. Dianalisis dengan uji chisquare didapatkan hasil $\rho=0,000$ dan $\alpha=$ 0,05 . Karena $\rho(0,000)<\alpha(0,05)$, maka hipotesis nihil ditolak berarti ada hubungan antara pendampingan suami dengan kelancaran proses persalinan atau dengan kata lain ibu bersalin yang didampingi oleh suami selama proses persalinan akan berjalan lancar sedangkan ibu bersalin tidak didampingi suami cenderung terjadi proses persalinan yang tidak lancar.

Hal ini menunjukkan bahwa pendampingan suami pada saat persalinan berpengaruh dengan kelancaran persalinan ibu, karena secara tidak langsung kehadiran seorang suami memberikan dampak positif pada psikologis ibu sehingga proses persalinan dapat berjalan lancar. Hal-hal yang dilakukan pendamping persalinan adalah memberi makan minum, mengatur posisi ibu senyaman mungkin, mengusap punggung ibu, bersama-sama dengan ibu melakukan latihan relaksasi, serta membantu kebutuhan ibu dan mendengarkan keluhan yang dirasakan ibu bersalin saat ada his. Ini sesuai dengan teori Indrayani (2013) 
yang mengatakan bahwa kehadiran seorang pendamping persalinan secara terus menerus akan membawa dampak yang baik pada proses persalinan karena dapat memberikan rasa aman, nyaman dan semangat serta dukungan emosional yang juga dapat membesarkan hati ibu, mengurangi rasa sakit dan mempercepat proses persalinan.

Pendamping persalinan tidak mutlak sebagai faktor utama dalam lancar tidaknya proses persalinan, namun jika hal ini diabaikan maka akan berpengaruh pada psikis ibu karena saat persalinan ibu bersalin sangat membutuhkan dukungan, semangat dari pendamping terutama suaminya. Sesuai dengan pendapat yang dikemukakan oleh Penny Simkin dan Ruth Ancheta (2005) bahwa pendamping persalinan bukan merupakan faktor internal, tetapi secara tidak langsung sangat berpengaruh terhadap psikis ibu sehingga dapat memberikan ketentraman pada hati ibu.

Jika selama proses persalinan ibu tidak ada dukungan dan semangat dari pendamping maka waktu persalinan dapat berjalan lama dan jika sudah melebihi garis waspada maka dapat berpengaruh juga bagi keselamatan bayi. Hal ini sesuai dengan pendapat yang dikemukakan oleh Simkin dkk, (2005) jika proses persalinannya tidak didampingi biasanya ibu bersalin ini akan merasa takut, cemas, merasa tidak aman dan nyaman sampai akhirnya dia akan merasa putus asa karena tidak ada yang memberikan semangat, sehingga timbul perasaan tegang. Hal ini akan menghambat proses persalinan yang akibatnya stres pada ibu dan bayi dapat terjadi, sehingga persalinan menjadi tidak lancar.

Pada hasil penelitian didapatkan ibu bersalin yang didampingi suami masih ada yang mengalami proses persalinan yang tidak lancar. Hal ini terjadi kemungkinan ada faktor lain yang mempengaruhi lancarnya proses persalinan yaitu psikologis dan kesiapan ibu saat mengahadapi persalinan. Karena meskipun ibu bersalin didampingi suami tetapi ibu sendiri tidak siap saat menghadapi persalinan sehingga ibu tidak tenang, hal tersebut akan berpengaruh pada psikologisnya yang mengakibatkan persalinan berjalan tidak lancar. Sesuai dengan Simkin, dkk (2005) ketakutan, kesendirian, stress atau kemarahan yang berlebihan dapat menyebabkan pembentukan katekolamin (hormon stress) dan menimbulkan kemajuan persalinan menjadi tidak lancar.

\section{SIMPULAN}

1. Ibu bersalin di BPM Arifin S Surabaya sebagian besar didampingi suami saat proses persalinan.

2. Ibu bersalin di BPM Arifin $S$ Surabaya sebagian besar mengalami proses persalinan yang lancar.

3. Ada hubungan antara pendampingan suami dengan kelancaran proses persalinan di BPM Arifin S.

\section{DAFTAR PUSTAKA}

Arikunto, Suharsimi. 2006. Prosedur Penelitian Suatu Pendekatan Praktik. Jakarta : Rineka Cipta.

Asrinah. 2010. Asuhan Kebidanan Masa Persalinan. Yogyakarta : Graha Ilmu.

Bobak, Irene. 2004. Buku Ajar Keperawatan Maternitas. Jakarta : EGC.

Depkes RI. 2004. Catatan tentang Perkembangan dalam Praktek Kebidanan. Jakarta : Depkes RI.

Indrayani, Djami. 2013. Asuhan Persalinan dan Bayi Baru Lahir. Jakarta : TIM.

Latipun. 2010. Psikologi Konseling. website

www.cdc.gov/pendampingpersalinan/training/glossary diakses pada tanggal 16 Mei 2014.

Lowdermilk, dkk. 2013. Keperawatan Maternitas edisi 8 buku 1. Jakarta : Salemba Medika.

Manuaba, IBG. 2007. Pengantar Kuliah Obstetri. Jakarta : EGC. 
Mukhoirotin, Khusniyah. 2010. Pengaruh Pendampingan Suami Terhadap Kecemasan Ibu Pada Proses Persalinan Kala I (Fase LatenFase Aktif). website : www.journal.unipdu.ac.id diakses pada tanggal 20 Mei 2014.

Nolan, Mary. 2004. Kehamilan dan Melahirkan. Jakarta : Arcan.

Notoatmodjo, Soekidjo. 2007. Pendidikan dan Perilaku Kesehatan. Jakarta : Rineka Cipta.

Notoatmodjo, Soekidjo. 2010. Metodologi Penelitian Kesehatan. Jakarta : Rineka Cipta.

Purnomo, Windhu. 2012. 36 Langkah Praktis Sukses Menulis Karya Tulis Ilmiah. Surabaya : Revka Petra Medika.

Rohani, dkk. 2011. Asuhan Kebidanan pada Masa Persalinan. Jakarta : Salemba Medika.

Rohma, Nikmatur. 2010. Pendidikan Prenatal Upaya Promosi Kesehatan Bagi Ibu Hamil. Jakarta : Gramata Publishing.
Simkin, Ancheta. 2005. Buku Saku Persalinan. Jakarta : EGC.

Sulistyawati, Ari. 2010. Asuhan Kebidanan Pada Ibu Bersalin. Jakarta : Salemba Medika.

Sumarah, Widyastuti. 2009. Perawatan Ibu Bersalin (Asuhan Kebidanan Pada Ibu Bersalin). Yogyakarta : Fitramaya.

Ujiningtyas, Sri Hari. 2009. Asuhan Keperawatan Persalinan Normal. Yogyakarta : Salemba Medika.

Varney, Helen. 2006. Buku Ajar Asuhan Kebidanan. Jakarta : EGC.

Waspodo, Djoko. 2008. Asuhan Persalinan Normal. Jakarta : JNPK-KR.

Wibowo, Arif, Lutfi Agus Salim. 2004. Implementasi Gerakan Suami Siaga di Kabupaten Nganjuk Propinsi Jawa Timur. Surabaya : Lembaga Penelitian Universitas Airlangga Surabaya.

Wiknjosastro, Hanifa. 2009. Ilmu

Kebidanan. Jakarta : YBP-SP. 